Revue

Revue de l'histoire des religions

de Ihistoire des religions

\title{
Translatio Andalusiae. Constructing Local Jewish Identity in Southern France
}

Translatio Andalusiae. La construction d'une identité juive locale dans le Sud de la France

\section{Ram Ben-Shalom}

\section{CpenEdition}

\section{Journals}

Electronic version

URL: http://journals.openedition.org/rhr/8739

DOI: ERREUR PDO dans /localdata/www-bin/Core/Core/Db/Db.class.php L.34 : SQLSTATE[HYOOO]

[2006] MySQL server has gone away

ISSN: 2105-2573

Publisher

Armand Colin

\section{Printed version}

Date of publication: 1 June 2017

Number of pages: 273-296

ISBN: 978-2-200-93126-1

ISSN: 0035-1423

\section{Electronic reference}

Ram Ben-Shalom, "Translatio Andalusiae. Constructing Local Jewish Identity in Southern France", Revue de l'histoire des religions [Online], 2 | 2017, Online since 01 June 2019, connection on 08 January 2021. URL: http://journals.openedition.org/rhr/8739; DOI: https://doi.org/ERREUR PDO dans / localdata/www-bin/Core/Core/Db/Db.class.php L.34 : SQLSTATE[HY000] [2006] MySQL server has gone away 


\section{Translatio Andalusiae Constructing Local Jewish Identity in Southern France}

This article explores the question of national group cohesion among the Jews of southern France. The numerous political borders and the expulsion of the Jews from Languedoc (1306) afford us the opportunity to examine local - Provençal - Jewish group identity, in contrast to a broader Jewish conception of nationhood. An analysis of some Hebrew documents demonstrates the significance of the expulsion of the Jews as the "destruction of my native land". This is one enlightening example of a unitary socio-cultural conception of the Provençal region, which did not recognize political borders. In contrast to the perception of global Jewish unity we find a historical consciousness of the unique local character of the region. The primary marker of this Provençal identity was their Andalusian Jewish tradition.

\section{Translatio Andalusiae. La construction d'une identité juive locale dans le Sud de la France}

Cet article explore la question de la cohésion d'un groupe national parmi les Juifs du sud de la France. Les nombreuses frontières politiques et l'expulsion des Juifs du Languedoc (1306) nous offrent l'opportunité d'examiner localement l'identité de groupe de ces Juifs, par contraste avec une conception plus large de la nation juive. L'analyse de certains documents hébraïques présente l'expulsion des juifs comme la "destruction de mon pays natal”. Il y a là un exemple éclairant d'une conception socioculturelle unitaire de la Provence qui ne reconnaissait pas les frontières politiques. La tradition juive andalouse constitue le premier marqueur de cette identité provençale.

* This research was supported by the I-CORE Program of the Planning and Budgeting Committee and The Israel Science Foundation (grant No. 1754/12). 
The Jewish centre in Southern France [the regions of Provence, Languedoc and Roussillon] lay at the heart of Jewish settlement in Western Europe - between the communities of Spain, Italy, France and Germany [Ashkenaz]. As a result of its geographical location, it not only absorbed elements of the cultures of neighbouring Jewish centres but also, in the course of forming its own independent and unique collective identity, spearheaded some of medieval European Jewry's most important cultural-religious developments. To cite only a few examples: the comprehensive project for the translation of philosophical and scientific works from Arabic into Hebrew, which facilitated the transmission and assimilation of the literary achievements of the Jews of Muslim Spain (al-Andalus); the creation of the Maimonidean-Aristotelian philosophical school, which provoked spiritual and socio-religious debate throughout the Jewish world; and the first known historical appearance of the esoteric discipline of Kabbalah - crucial to the emergence of Spain as a centre of Kabbalistic study.

Group identity is a complex and elusive construct that presents a variety of facets - contingent, inter alia, on the observer's perspective. In analysing group identity, we must ascertain the differences between the various social sub-groups and give utmost expression to them - in light of the available sources and their historical contexts, while considering the possibility of intentional silencing of one or more sub-groups, and the manner in which collective historical memory is formed, including an inherent process of selection and preference.

It is not my intention in the present article to provide an unequivocal and comprehensive definition of the cultural identity of the Jews of Southern France in the late Middle Ages, but rather to identify a single component of identity, which acquired particular importance in times of crisis and among members of an elite intellectual sub-group in positions of leadership and influence. In the first part of the article, I will mainly examine two literary sources - an ethical tract and a letter - both written in the aftermath of the expulsion of French Jews from Languedoc (1306). An analysis of these sources will allow us to explore the 
question of national group cohesion among the Jews of Southern France, who had long lived under a number of separate political entities, including the Kingdom of France, the county ruled by the House of Anjou and the Kingdoms of Aragon and Majorca. The numerous political borders between the Alps and the Pyrenees and the expulsion of the Jews from one of the political units within this geographic area afford us the opportunity to examine local - Provençal - Jewish group identity, in contrast to a broader Jewish conception of nationhood. In the second part of the article, I will explore a central element of local Jewish group identity, reflected in the ideology and range of symbols and slogans employed by the Provençal group of philosophers for the purposes of propaganda, in the face of the frontal cultural attack they suffered at the hands of central Jewish figures in neighbouring Spain, foremost among them Solomon Ibn Adret (Rashba; 1305).

\section{"Provinșah" (Jewish Provence) as a Native Land: The Notion of a Local National Group}

The expulsion of the Jews of France in 1306 was not the first political expulsion to take place on European soil. Regional expulsions of Jews had occurred in France, beginning in 1182. Nevertheless, it was a catastrophe and a psychological and historical trauma that abruptly wiped out centuries-old communities, with deep local roots and distinct, independent, cultural identities and histories. Contemporary Jewish literature reflects the great catastrophe that befell the Jews of France in general and the Jews of Languedoc in particular. ${ }^{1}$ Qalonymos ben Qalonymos (1278-1343), in his book Even bohan [Touchstone], described the suffering of his Jewish neighbours from the province of Languedoc. He himself lived in the city of Arles, which lay to the east of the Rhône, in the County of Provence, under the House of Anjou, and was therefore not included in the expulsion order. Qalonymos travelled extensively between Southern France, Italy

1. See Susan L. Einbinder, No Place of Rest: Jewish Literature, Expulsion, and the Memory of Medieval France, Philadelphia, University of Pennsylvania Press, 2009, pp. 61-83. 
and Catalonia, and when he wrote Even bohan, in 1323, he resided in Barcelona:

A number of times, for fear of the tribulations of misfortune that occur, I have heard it said to the mountains, "Cover us! Hills, fall upon us!" I am too anguished to hear the evil that has come upon my people, too frightened to see the destruction of my native land. My soul is impatient with the travail of Israel, as the spirit of the ruler has risen up against us these seventeen years to place my people at the head of the column of exiles. Over the holy flock he stretched a line of chaos; he overturned them in his wrath and with a strong arm drove them from his land to everlasting abhorrence. He moved them town by town, naked and lacking everything. Those who had stored much gold in their palaces are desolate in the streets. Those who had dwelled like a king among his troops, in their courts and castles, embrace dunghills. For the upheaval of the days, when their rage burned against us to annihilate and destroy the elders of the generation and its officers; for the guardians of the law, swallowed up by the earth, my soul loathes my life! ${ }^{2}$

Provence - Provinșah - as understood by Jews at the time, stretched from the Alps to the Pyrenees, and it was this region that Qalonymos considered his "moledet" or "native land". The primary meaning of the word "moledet" is the place in which one was born, where one's family lives. Already in the Bible, however, the word became charged with deep emotional-cultural meaning. For example, in Jeremiah 22:10: "but weep bitterly for he who goes away, for he shall return no more, nor see his native country [moladeto]". ${ }^{3}$ In the book of Genesis we find expressions such as 'eres moladeti ("the land of my birthplace"; 24:7) and 'arsecha umoladetcha ("your land and your birthplace"; 12:1), which the Provençal interpreter David Kimhi (Radak) explains as follows: "From your land - Because it is hard for a man [i.e. Abraham] to leave his land - where he has resided for a long time; a fortiori if he was born there. That is why it [also] says 'and from your birthplace'." And Nahmanides, polemicizing with Abraham Ibn Ezra, writes:

Because Haran is his land, and that is where he was born, and it had been the land of his fathers since ancient times, and that is where he was

2. Qalonymos ben Qalonymos, 'Even bohan, ed. A. M. Haberman, Tel Aviv, Mahbarot le-sifrut, 1956, pp. 113-114.

3. See Eliezer Ben-Yehuda, Milon ha-lašon ha-ivrit ha-yešanah ve-hahadašah, Jerusalem and Tel Aviv, La 'am, 1948, vol. 6, p. 2846, s.v. "moledet".

4. See David Kimhi (Radak), commentary ad loc., in Miqra'ot gedolot. 
commanded to part from them.... And the reason it says "your land and your birthplace and your father's house", is because it is hard for a man to leave his land, [the land] in which he resides and where his loved ones and his friends are; a fortiori when it is the land of his birthplace, where he was born; and a fortiori when the entire house of his father is there. And that is why He had to tell him to leave everything, for his love of the Holy One, blessed be He. ${ }^{5}$

Qalonymos here employs the words of Esther (8:6) "the destruction of moladeti", referring to Haman's plot (ibid. 5) "to destroy the Jews that are in all the king's provinces". Although the literal meaning in the book of Esther would appear to be "kindred" or "family" - paralleling " "ammi" (my people) in the same verse I believe that Qalonymos, whose family was not among the exiles, uses moladeti here in the sense of "birthplace", following common usage, as well as the primary sense of the word in the Bible, generally coupled with the word 'ereș (land); and, as Abraham bar Nathan from Lunel, author of Sefer ha-manhig, emphasises: "There is no custom for this in Provinșa moladeti". 6

This linguistic-cultural context, which expresses a deep bond to a particular place, allows us to understand the significance of the expulsion from Languedoc as the "destruction of my native land". Although he himself was not a victim of the expulsion from the French province of Languedoc, we see from Qalonymos' words that the boundaries of his "native land" were not determined by the political borders between the County of Provence and Languedoc. As far as Qalonymos was concerned, Languedoc was the centre of Provinșah, home to important Jewish communities, such as Narbonne, Montpellier, Béziers and Lunel. This is one enlightening example of a unitary socio-cultural conception of the region of Southern France, which did not recognise the political borders drawn and redrawn by kings and counts, for centuries. Like the Jews, the Christians of the South, beginning in the eleventh century and still in the thirteenth century, sometimes referred to the entire area as Provence. The Occitan mother tongue was shared by

5. Nahmanides (Ramban), commentary on Genesis 12:1, in Perušei ha-Torah le-Rabbeinu Mošeh ben Nahman, ed. C. D. Chavel, Jerusalem, Mosad Harav Kook, 1959, vol. 1, p. 76.

6. Abraham bar Nathan ha-Yarhi, Sefer ha-manhig, ed. Y. Raphael, Jerusalem 1978, Hilkhot 'erusin ve-niśs'in, sec. 107. 
Jews and Christians alike. Both societies had deep historical roots in the area. Their collective identity was shaped by local traditions, expressed, time and again, in the form of common myths as well, such as the legend of Charlemagne - a hero to both Jews and Christians - who liberated the region from the common Muslim enemy. ${ }^{7}$ For centuries, the political ambitions of the Christians of Southern France did not coincide with those of the French monarchy and aristocracy to the North. Local unity and opposition to foreign forces was also reflected in the religious heresies of the "Good Men" (Cathars) and the Waldensians, as well as in social unrest and political opposition to the officials of the Crown and, later, in the sixteenth century, in the support of the residents of the South for Protestantism. As early as the mid-thirteenth century, the Jews and the Christians of Southern France shared a common enmity toward the domineering Kingdom of France. The Maimonidean Halakhist Isaac ben Yedaiah, for example, applied the words of Jeremiah (1:14), "Out of the north the evil shall break forth", to the Kingdom of France - claiming that the French monarch and aristocracy had treated them and all previous generations with cruelty, and abused their power and sovereignty. ${ }^{8}$ All of this may explain the extent of the shock felt by the author of 'Even bohan at the "destruction of his native land" and the eradication of the communities of Languedoc. Furthermore, Qalonymos stresses the absolute novelty of this expulsion, and the fact that the Jews of Southern France had never before experienced such cruelty:

From my youth to this day, they swarmed round me, oh they surrounded me, beyond the natural hardships that are the same for all members of the race and the times that I [myself] have experienced,

7. Aryeh Grabois, "Demuto ha-'aggadit šel Qarl ha-gadol ba-meqorot ha- 'ivriyim šel yemei ha-beinayim”, Tarbiz 36/1 (1966), pp. 22-58; Jean Régné, "Étude sur la condition des Juifs de Narbonne du ve au XIV siècle", Revue des études juives (REJ) 55 (1908), pp. 23-27; Israël Lévi, "Le roi juif de Narbonne et le Philomène", REJ 48 (1904), pp. 197-207; Joseph Shatzmiller, "Politics and the Myth of Origins: The Case of the Medieval Jews ", in G. Dahan (ed.), Les Juifs au regard de l'histoire: Mélanges en l'honneur de Bernard Blumenkranz, Paris, Picard, 1985, pp. 49-61.

8. See Isaac ben Yedaiah, Commentary on Midrash Rabbah (New York, Library of the Jewish Theological Seminary of America, MS 5028, ff. 36v-37r), in Marc Saperstein, Decoding the Rabbis: A Thirteenth-Century Commentary on the Aggadah, Cambridge MA, Harvard University Press, 1980, p. 187, q.v. 
evil [things] of which my fathers and my fathers' fathers did not see the like. Times in which I preferred death to life?

The expulsion tore a deep rift in the heart of the cultural entity of the Jews of Southern France, the boundaries of which extended beyond the political borders of France. The extent of the pain and suffering, and the eradication of the leading communities of Provençal Jewry, are reflected in greater detail in another written testimony (possibly the most important and remarkable extant source!), penned by one of the victims of the expulsion. I am referring to the letter of Simeon ben Joseph Duran, written some five months after the general expulsion, and two months after the expulsion of the Jews of his community of Montpellier:

The great mountain Montpesler [Montpellier], from the stones of which were cut a number of gems and a place for gold, the mountain God has desired, a palace He built for His abode. Surrounded by a wall of justice, and faithfulness is the girdle of its waist. City of the mighty, the teaching of kindness is on her tongue. There grazes the suckling calf, wisdom cries out in her squares. In its dwellings, flocks of companions lie, rousing their bodies with Midrash, Talmud and Mishnah. And there the wolf and the leopard rest and graze, their young lie down together with none to cause fear, and their couch is leafy. We have a little sister [Israel or the Torah] banished from the house of pleasure, given into the hand of a northern people ['am safon, the Chaldeans, following Jeremiah 6:22; a veiled reference to the Kingdom of France]. They [the French troops] have come up the mountain [Montpellier], and she [the Torah] has gone down to the lowest covert of the cliff.... And is it any wonder, with your voice in my ears, that my soul offers itself in restitution, that it roars mightily because of her woe? ... For these things can I be silent and restrain myself $\ldots$ at the perishing of a [sister] born [moledet - also "birthplace" or "native land"] in the household or born outside [Leviticus 18:9]? ... They have killed my young men, kidnapped my sons and daughters and [practised] oppression in the province ... the slain on my heights, desolation and destruction within my borders. Should I not weep bitterly at such a time as this and should hatred not arise in my heart? ${ }^{10}$

The expulsion of the Jewish community of Montpellier, which had been ruled, until then, by the king of Majorca (as a vassal of the

9. See Qalonymos ben Qalonymos, 'Even bohan, p. 113; Susan L. Einbinder, "Recall from Exile: Literature, Memory and Medieval French Jews", Jewish Studies Quarterly 15 (2008), pp. 225-240

10. Letter by Simeon ben Joseph Duran, in David Kaufmann, "Deux lettres de Simeon Ben Joseph En Duran de Lunel”, REJ 29 (1894), pp. 225-226. See Gérard Nahon, "Le figuier du Seigneur. Relations Hébraïques Méridionales des exiles de 1306", in D. Iancu-Agou (ed.), Philippe le Bel, Paris, Cerf, 2012, esp. pp. 224-229. 
king of France), was perceived as the act of an occupying foreign power, rather than that of a sovereign ruler within his own realm. It is the French troops ( 'am șafon) who "come up the mountain" - the centre of Torah study at Montpellier, compared to the Temple rather than the students of the Torah, "the clean of hands and the pure of heart", whose prerogative it is, according to Psalms 24 (vv. 3-4). Like Qalonymos, Duran sees Montpellier as a moledet, a native land. The deep, sentimental bond to the land is further underscored by Duran's allusion to Leviticus 18:9: "The nakedness of your sister, your father's daughter or your mother's daughter, born [moledet] in the household or born [moledet] outside - you shall not lay bare her nakedness." In citing this passage, Duran appears to be saying that the relationship may sometimes be a complicated one - as in times of expulsion - but even a sister "born outside" (which both Rashi and Nahmanides explain as the child of an illicit union), is still a sister, whose loss would be devastating. ${ }^{11}$

Estori ha-Parhi, who wandered, at the time of this expulsion, from Montpellier to Barcelona and, finally, the Land of Israel, described the loss of his country, as follows:

I was taken from school, stripped of my robe, dressed in the garments of exile; in the midst of my studies I was expelled. Naked I left my father's home and the land of my birth [moledet]; I walked barefoot. A boy, I wandered from nation to nation and kingdom. I was driven to a people whose language I did not know. I found no rest [until] the King to whom peace belongs brought me into his chambers, from captivity to the Land of Beauty [the Land of Israel]. ${ }^{12}$

Ha-Parhi too gives prominence in his description to the destruction of the cultural centre at Montpellier, when his studies there were suddenly interrupted. He found metaphorical, spiritual respite - from the loss of his native land and the hardships of exile - only when he finally reached the Land of Israel.

This deep connection between the Jewish people of Southern France and their land was apparently well-known, and its expressions

11. See Rashi on Leviticus 18:9, and Nahmanides ad loc.

12. Estori ha-Parhi, Sefer kaftor va-ferah, ed. A. M. Luncz, Jerusalem, 1897, introduction, p. 3. See Heinrich Graetz, History of the Jews, Philadelphia, Jewish Publication Society of America, 1956, vol. 4, pp. 48-49. See also Michael McVaugh and Lola Ferre, The Tabula Antidotarii of Armengaud Blaise and Its Hebrew Translation, Transactions of the American Philosophical Society, Philadelphia, American Philosophical Society, 2000, pp. 10-14. 
can be found in the later Jewish historiography. In Ševet Yehudah (probably written for the most part in Portugal in the early sixteenth century), for example, Solomon Ibn Verga described the dynamics of the return of the Jews to France, following an invitation from King Louis X, in 1315. At first, they declined, citing fears of popular hostility, but later they changed their minds, saying, "Let us return to our native land, because she is our mother, and the king is good and upright." ${ }^{13}$ Thus, although the exiles had already resided for some nine years in various Jewish communities in the Iberian Peninsula and despite their real fears, they were unable to resist the pull of their native Languedoc and Roussillon.

Provençal Jewish cultural identity was a central element in the powerful attraction the exiles felt for their country. In Spain, where they had settled in independent and prosperous communities, they could not continue to preserve their distinct Provençal identity. Historical conditions had changed, however, by the time of the final expulsion from the County of Provence (May 1500 and July 1501), ${ }^{14}$ when some of the Jews of Provence settled in autonomous communities in the Ottoman Empire, alongside groups of exiles from Spain and others.

In a letter sent, in 1550, by the "community of the expulsion from Provence" in Salonica to the Jews of Provence living under papal rule in Avignon and the Comtat Venaissin, the former urge the latter to leave the domain of the Church and join them in Salonica, to live well under the Ottoman crescent. They stress that their motives are selfless, stemming "only from love of the good for its own sake; [as] we are all the sons of one man". ${ }^{15}$ Thus, two generations after they had left the region of the former County of Provence, the Provençal exiles still viewed the remaining Jewish communities in France as members of the same cultural group, sharing a common language

13. Solomon Ibn Verga, Ševet Yehudah, ed.A. Shohat and Y. Baer, Jerusalem, The Bialik Institute, 1947, p. 70. On Ševet Yehudah, see Jeremy Cohen, "Polemic and Pluralism: The Jewish-Christian Debate in Solomon ibn Verga's Shevet Yehudah", in I. J. Yuval and R. Ben-Shalom (eds.), Conflict and Religious Conversation in Latin Christendom, Turnhout, Brepols, 2014, pp. 167-190.

14. See Danièle Iancu, Les Juifs en Provence (1475-1501) de l'insertion a l'expulsion, Marseille, Institut historique de Provence, 1981, esp. pp. 110-124, 193-202.

15. Letter of the "community of the expulsion from Provence", in Isidore Loeb, "La correspondance des Juifs d'Espagne avec ceux de Constantinople", REJ 15 (1887), p. 271. 
and customs. Should they accept the invitation and come to Salonica, the exiles write, "we will become a great and excellent camp, a congregation in the land, also because we will be close to you and you will be close to us". ${ }^{16}$ They sought to strengthen the cultural vitality of the Provençal group, in order - as we know today - to prevent their assimilation into the Spanish communities. They stress that all of the Provençal communities belong to a single entity ("sons of one man"). To illustrate, they proudly list the surnames (present in both Salonica and Avignon) of distinguished Provençal families: "And there also remain among us today [members] of all of the families distinguished in honour and glory in all of the districts of Provence: from Kaspia [L'Argentière] the Kaspi family, from Cadenet the Cadenet family, and all of the other distinguished families we have not listed for hatred of lengthiness - many honoured ones among us for Torah and for testimony (Isaiah, 8:20)." ${ }^{17}$ From the letter, we learn of the importance the authors ascribed to Provençal identity, and of their efforts - ultimately unsuccessful - to safeguard it against assimilation and extinction. What did the collective identity of Provençal Jews comprise that the surnames Kaspi or Cadenet were supposed to embody?

\section{Who Were the “True” Heirs of Jewish Al-Andalus?}

The cultural identity of the Jews of Southern France was shaped over the course of centuries and included many components, of which I will mention a few: founding myths that highlighted their connection to exiles from Jerusalem during the Second Temple Period, and to the Babylonian branch of the exilarchy (House of David); unique religious customs, the preservation of which was, at times, marked by struggle against the influences of neighbouring centres; the importance ascribed to the Neśi 'im at Narbonne, who enjoyed aristocratic standing and feudal authority, and under whose patronage the centre of Torah study at Narbonne was established; the yeshivot at Lunel, Posquières and Béziers, which attracted students from near and far; pietist groups that developed

16. Ibid.

17. Ibid. pp. 271-272. 
within the circle of the yeshivot and, in part, dedicated themselves to esoteric, Kabbalistic study; the mobility of Provençal scholars who were thus exposed to new ideas and methods in Halakhah and the sciences, which they brought back with them; the resettlement of immigrants from Al-Andalus (the Kimhi and Ibn Tibbon families) in the centres of Torah study in Southern France; the openness of the leaders of the yeshivot to the sciences, which turned them into patrons of the cultural revolution that took place in Provence, Languedoc and Roussillon, which, in turn, led to a transformation of Jewish education throughout the world; the close connection that developed between the yeshivah at Lunel and Maimonides in Egypt - a type of Mediterranean discourse that, inter alia, gave rise to the spiritual-intellectual project of Samuel Ibn Tibbon, who founded the Maimonidean school in the fields of Halakhah and philosophy; the unique development of Provençal Hebrew poetry, which was influenced both by the poetry of Spain and by the songs of the Provençal troubadours; the ideological clash between the Kabbalistic and philosophical movements, which was linked, in Southern France, to a series of controversies concerning Maimonides' works and the issue of extreme allegory. ${ }^{18}$

The saying "All Jews are responsible for one another" 19 typifies the pervasive sense of Jewish unity in the Middle Ages, across the diaspora and its various centres of Jewish life, such as Sefarad, Italy and Ashkenaz. This approach may also be observed in the authority assumed by some Jewish centres to interfere in the affairs of other Jewish centres and to try, in the name of Jewish unity, to impose their own views on other communities. One such case concerns the controversy over radical philosophical allegorisation that raged between 1303 and 1306, and in which R. Solomon ben Adret (Rashba), leader of Aragonese Jewry, played a central role. Ben Adret issued bans (1305) against groups of Jews in the neighbouring centre of Southern France, and sought to restrict the fields of study pursued by Provençal Jews. ${ }^{20}$

18. See: Ram Ben-Shalom, The Jews of Provence: Renaissance in the Shadow of the Church [Hebrew], Raanana, 2017.

19. See, for example, BT, Shevuot 38a.

20. See Ram Ben-Shalom, "The Ban Placed by the Community of Barcelona on the Study of Philosophy and Allegorical Preaching - A New Study", REJ 159 (2000), pp. 387-404; Gregg Stern, Philosophy and Rabbinic Culture: Jewish 
In contrast to this perception of Jewish unity and mutual responsibility, we find, among a core group within Provençal Jewry, a historical consciousness of the unique character of the Jewish centre in Southern France. This local consciousness is apparent in Jedaiah ha-Penini's 'Iggeret ha-hitnașlut [The Epistle of Apology], to Solomon ben Adret.

According to Jedaiah ha-Penini, he sent his writ of defence not because of the ban on the study of philosophy imposed by Ben Adret, but because of a letter that Ben Adret had sent to the Jewish communities of Sefarad (Aragon, Castile and Navarre), containing serious accusations against the Jews of Southern France (Provinșah). Furthermore, he writes, he had also heard a rumour (for which no basis has been found to date) that Ben Adret had sent similar letters to the communities of Ashkenaz and France (Sarfat). The gravest problem to Jedaiah's mind was thus the fact that Ben Adret had maligned the communities of Provence, Languedoc and Roussillon. As long as the controversy had only involved Southern France and Catalonia, the calumny could be tolerated. Once Ben Adret departed from the limited Marseille/Montpellier - Barcelona track, however, a trenchant response was required, and Jedaiah bent to the task.

'Iggeret ha-hitnașlut was of great importance. We must remember that this apologia, like many letters written at the time, was not intended merely for Ben Adret's eyes, but was disseminated throughout Southern France and Spain, as part of the propaganda of the philosophers' camp, and through ordinary channels as well. ${ }^{21}$ One testament to the significance of Ha-Penini's letter is Megillat ha-hitnașlut ha-qatan [The Minor Epistle of Apology], written by Qalonymos ben Qalonymos at the height of the crisis between Southern France and Catalonia, following the pronouncement of the bans of excommunication at Barcelona and before the expulsion of the Jews from France (1306). As a native of Arles, fully aware of the pride of Provençal Jews in their independent

Interpretation and Controversy in Medieval Languedoc, London and New York, Routledge, 2009..

21. See Abraham S. Halkin, "Yedaiah Bedershi's Apology", in A. Altmann (ed.), Jewish and Renaissance Studies, Cambridge MA and London, Harvard University Press, 1967, pp. 165-184; Ram Ben-Shalom, «Communication and Propaganda between Provence and Spain: The Controversy over Extreme Allegorization 1303-1306 », in S. Menache (ed.), Communication in the Jewish Diaspora: The Pre-Modern World, Leiden, Brill, 1996, pp. 214-215. 
identity, Qalonymos felt the awkwardness created by his presence and study at Ben Adret's academy, at the height of a controversy that had also become a struggle over cultural identity. In his epistle, he explains why he chose to study in Barcelona rather than at one of the many centres of Torah study and scholarship in Provence, Languedoc and Roussillon. Toward the end of the work, he also offers the following explanation of the name Megillat ha-hitnașlut ha-qatan:

Read this epistle and examine my reasoning, and show it to all of the great men of the city ... and should one or two come from another city and ask about me, defend me as called for and show him this epistle. And distinguish between this and the one composed by the universal [= philosophical scholar] unparalleled brother Don Bonet Abram [Jedaiah Ha-Penini's Provençal name], may his Rock preserve him and give him life, for the controversy of wisdom that he called writ of apology, I have called my treatise the minor apology. ${ }^{22}$

The weight and importance of Ha-Penini's Apology were so great in Qalonymos' eyes, that he decided to name his own work The Minor Apology. The fact that he did so is indicative, in my opinion, of the way in which Ha-Penini's epistle was received by the Jews of Southern France in general. It was not just another letter - one of the dozens or hundreds exchanged between the centres over the course of the controversy, some of which were published in Abba Mari's Minhat qena'ot. It was, in fact, a work in its own right, in which the author - in response to attacks from the neighbouring cultural centre in Catalonia - traced and defined the collective identity of Provençal Jews. It is thus worthy of particular attention in the context of the present analysis of that identity.

In 'Iggeret ha-hitnașlut, Jedaiah ha-Penini refers to the scholars of the centres of Torah study in Southern France as "the sages of this holy land". These sages are said to disseminate Torah (in the broad sense of Halakhah, Talmud, Midrash, philosophy and the sciences), which he compares to gold and calls "the Torah of these provinces". ${ }^{23}$ Ha-Penini's Provinșah was a clearly defined

22. Qalonymos ben Qalonymos, Megillat ha-hitnașlut ha-qațan, in J. Shatzmiller, “Megillat ha-hitnașlut ha-qațan' le-Rabbi Qalonimos ben Qalonimos", Sefunot 10 (1966), p. 51.

23. Jedaiah ha-Penini, 'Iggeret ha-hitnașlut, in Še'elot u-tešuvot ha-Rašba', Jerusalem, Makhon Yerushalayim, 1997, vol. 1, sec. 418, p. 206; and in Manuel Forcano i Aparício, La Lletra Apologètica de Rabí Iedaia ha-Peniní: Un episodi 
geographical area, identified with the main communities along the coast, from Narbonne to Marseille, those of the Comtat Venaissin and others. ${ }^{24}$ This geographical-cultural centre, blind to its inner political borders, had its own ancestral traditions ("our holy ancestors") but now, due to the attacks levelled against it by Solomon Ben Adret, this "holy land" (holy by virtue of its Torah and its ancestors) had been turned upside down and its ways completely changed; ${ }^{25}$ it was isolated by Ben Adret's bans and vilified everywhere, by means of his effective propaganda. ${ }^{26}$

\section{Particularly interesting is the passage in which Jedaiah offers} an overview of the literary-cultural history of Provençal Jewry, centred around the influence exerted by Spanish philosophical and scientific thought, introduced through books and the teachings of

de la controvèrsia maimonidiana a Catalunya i Provença, Barcelona, Universidad de Barcelona, 2003.

24. Jedaiah ha-Penini, 'Iggeret ha-hitnașlut, in Še'elot u-tešuvot ha-Rašba', vol. 1, sec. 418, p. 207: "And what have you deemed in our belief today, sirs, death and bereavement - beyond what is already known of the belief of our rabbis in Narbonne and Béziers and Lunel and Montpellier and the other communities of Provence (Provinșah) and Venaissin until Marseille - that you have singled out these regions today for ill and made an example of them?"

25. Ibid., p. 206: "Woe to you, land. Once like the garden of Eden, you have been made an abomination; a derision and a curse, rather than the beauty and joy you used to be. What has God done to us? A holy land, where there was good gold from the earth's beginning and whence shepherds and corner-stones came, has become like cities led into idolatry ( $k a$ - 'arim ha-nidahot) overturned by God; the rock our holy ancestors quarried and the pit our perfectly-learned elders dug. You will no longer be called virtuous, but dark land and land of gloom."

26. Ibid., p. 207: "Indeed that which had frightened us, and made our ears ring when we heard of it, and which destroyed and devastated us [was] the letter sent by our master [Solomon ben Adret] in the lands of Sefarad. And we saw it [the letter] with our eyes. It caused us a disgrace and head-wagging [when it reached] the ears of our brethren at the corners of the earth. And its like, we were told, was sent to the far reaches of Ashkenaz and France, as if issuing a ruling that this land must be destroyed [also: banned] and its name blotted out like that of the seed of Amalek - [i.e.] for as long as those views that you have ascribed to us [in the matter of extreme allegory] persist, the divine name and the divine throne will not be complete. And what will the sages in the far reaches [Ashkenaz and France] do when they hear this evil report? They will truly believe the voice of the first sign, and observe and obey the words of our master [Solomon ben Adret], because his name is great in their land, and [even] the most insignificant of his utterances cannot be contested in all their lands. And when they arise as one man, enraged against this young goat, the region of Provinșa and its suporters (ha-nilve 'elav), it will truly be torn apart as swiftly as a kid is torn by countless lions, extinguishing our last remaining ember. And from whom, if not from you, will our blood then be requited?" 
exceptional sages who had come to Southern France from Spain. This historical overview is certainly teleological, intended to dispel the widespread popular view regarding the corporeality of God. According to Jedaiah, the origins of the doctrine of corporeality can be traced to the period in which the Jews went into exile. In Muslim lands (from Babylonia to Spain), however, there arose Jewish scholars who were fluent in Arabic and could read and study Arabic translations of Greek science. On the basis of this experience and employing the tools of scientific knowledge they had acquired, some of these Jewish scholars also began to examine the Torah and analyse its doctrines and views. In particular, they made use of external philosophical knowledge to repudiate the simple faith in divine corporeality. Here Jedaiah outlines the progression of philosophers who fought against the belief in corporeality, whose books and teachings influenced the Jews of Southern France and shaped their cultural identity:

And the best known of all of the early ge 'onim of the sefaradim (and their sages), whose fame reached us, was the great $g a^{\prime}$ on Rabbi Saadia Pitomi [Saadia Gaon], who enlightened the eyes of future generations with his precious works, of which he gave us his philosophical commentary on Sefer yeșirah [Book of Creation], followed by Sefer ha-'emunot [ve-ha-de 'ot; Book of Beliefs and Opinions].... And after him many of the later [sages] of the sefaradim of those of whom we have heard. Among them, Rabbi Isaac ben Giat [1038-1089, Lucena, Spain], from whom they [should be: we] have a beautiful commentary on Kohelet, which demonstrates matters of wisdom, and piyyutim. Also many recount words of wisdom attributed to him, during the Days of Repentance. And from Rabbi Moses ben Ezra the salah [composer of selihot - penitential piyyutim], we also have a book called 'Arugot ha-bosem, [Beds of Spice] which very much follows in the footsteps of the philosophers in many matters. And the sage Rabbi Solomon Ibn Gabirol [1070-1021/2], from who we have a short book on the qualities of the spirit [tiqqun middot ha-nefes'], based on natural principles. And Rabbi Judah ha-Levi distinguishes himself in matters of wisdom in his wonderful praises and piyyutim. And from him we also have Sefer Kuzar [The Kuzari]. As we have received it, he masterfully investigated and explained the secrets of the Torah and the Prophets, on the basis of the concord of faith and reason, with all his might, more than any who came before him. And the Naśi Rabbi Abraham [bar Hiyya], known as Hibah 'Alšurța [Șāḥib al-Shurța - an honorific meaning chief of the captains], who also engaged in philosophical enquiry and profound study of the seven wisdoms. And from him we have many books of mathematics, geometry, astronomy and astrology, and also of human nature and the secrets of the Torah, 
a book called Sefer ha- 'adam [Book of Man; perhaps a reference to Hegyon ha-nefeš ha- 'așuvah (Meditation of the Melancholy Soul)]. And two sages, of whose time we are uncertain, the one - Rabbi David ha-Bavli, called Al-Muqammiș [Daoud ibn Marwan al-Muqammis of Nisibis, probably active in the first half of the ninth century], from whom we have a book called after his own byname [Al-Muqammis = 'Ishrūn Maqālāt (Twenty chapters)], in which he strives to present proof based on enquiry, of the known principles of faith, and to dispute by means of such proof, the claims of the heretics and to refute them. And the second, is called Rabbi Joseph [Ibn Saddiq, twelfth century], from whom we have a book called Olam qațan [Small World] - a compendium on natural science with the elucidation of a few (secrets of the Torah). Among the greatest physicians of our people is also Rabbi Isaac Israeli [died circa 950], of whose works we have - besides [works on] medicine - a good commentary on Sefer yeșirah, based on natural principles, and the treatise Yishreșu ha-mayim [Let the Waters Swarm] on a question he raised regarding the intention of the Torah in that verse [Genesis 1:20]. And his reply is founded on the pillars of tradition and reason alike. And like him, the sage and physician Rabbi Isaac ben Muqatil [unknown today], from whom we also have a short treatise on natural science in all-encompassing chapters and on most matters of that science, in a brief fashion. And so too the grammarian Rabbi Jonah ibn Janah, who prefaced his great work, Sefer ha-riqmah [Book of the Many-coloured Flower Beds], with many necessary rules for his craft, deduced by logic, and some also taken from nature [physics]. And he cited in his book many commentaries of many verses that accord with reason. ${ }^{27}$

This is a cultural history, albeit incomplete and apologetic, that traces one important aspect of the formation of the Jewish centre in Southern France. According to Jedaiah, the philosophical works of Sefarad (beginning with the writings of Rabbi Saadia Gaon, in Babylonia; even noting Daoud al-Muqammis, who lived before Saadia - a fact unknown in Jedaiah's time) occupied the greater part of the literary corpus of Provençal Jewry. In many ways, this is the very corpus represented in the library that Samuel Ibn Tibbon inherited from his father Judah, and which he enriched with those works of Maimonides written after Judah's death. The cultural identity of the Jews of Provence was, in fact, that of al-Andalus, in the spirit of the agenda shared by Joseph Kimhi and Judah Ibn Tibbon. Jedaiah's interest, however, lay not in $a d a b$ in general, but specifically in philosophy, which is why

27. Jedaiah ha-Penini, 'Iggeret ha-hitnașlut, in Forcano i Aparício, La Lletra Apologètica, pp. 395-397. 
he focused on the philosophical writings of the Jews of Sefarad. Halevi's Kuzari is also included in this category, although it is, ostensibly, a work that attacks philosophy. According to Bernard Septimus, the Kuzari does not reject the philosophical tradition but, rather, offers a response from within the tradition to the challenges of that time, and that is how, he believes, Jedaiah ha-Penini saw it as well. ${ }^{28}$ In this, Jedaiah reflected a widespread view in Southern France that the Kuzari was an esoteric work that supported the rational approach. ${ }^{29}$ Jedaiah makes no mention of the extensive library of philosophical works written by Provençal scholars over the course of the thirteenth century, as his purpose was to demonstrate to the Spanish (Catalonian) leader the nature and essence of the Provençal philosophy he had condemned and banned. Jedaiah sought to show that the thought of the Jews of Southern France was a branch and continuation of the tradition of Sefarad that had culminated in the work of Maimonides. Jedaiah claimed that the philosopher-Jews of Provence, Languedoc and Roussillon were, in fact, the true Sefaradim - even more so than Ben Adret and his circle who actually lived in Spain. The designation sefaradi was thus, to Jedaiah's mind, more cultural than territorial. The Jews of Southern France, according to Jedaiah's cultural history, were the true heirs of Sefarad, in the sense of al-Andalus and its culture.

In so doing, Jedaiah offered a sober analysis of the processes of change experienced by Spanish Jewish society beginning in the second half of the twelfth century and especially after the debate concerning the Guide of the Perplexed (around 1232). Although there remained in the kingdoms of Christian Spain cultural and social islands of the old Andalusian Jewish aristocracy, broad swathes of Jewish society there (including part of the courtier class) had undergone a transformation, absorbing other values, under the leadership of the scholars and Kabbalists of Girona and Barcelona, in Aragon - of whom Solomon ben Adret was

28. Bernard Septimus, Hispano-Jewish Culture in Transition: The Career and Controversies of Ramah, Cambridge MA, Harvard University Press, 1982, pp. 62, 148 n. 11.

29. Peruš qadmon le-Sefer Kuzari: "Hešeq Šelomoh” le-Rabbi Šelomoh ben Yehudah mi-Lunel, ed. D. Schwartz, Ramat Gan, Bar Ilan University Press, 2007, pp. 8-9. 
one - and the circles of Meir ha-Levi Abulafia (Ramah) and Judah Alfakar in Toledo and Burgos, in Castile. The standard of Andalusian values in Spain was raised by the high-born courtier aristocracy, which ran most Jewish affairs until the rise, in some communities, of a scholarly social elite that rebelled against the aristocracy and supplanted it. ${ }^{30}$ In Southern France as well, a distinguished leadership elite identified with the values of al-Andalus, although unlike in Spain, this elite did not rely on lineage, sacrosanct inherited privileges or personal concessions granted by the Crown. It was a scholarly bourgeois elite, which derived its standing from its own intellectual achievements, winning the support of the yeshivot and their leaders. The replacement of the old aristocratic leadership in Southern France - the Nesi im of the House of David at Narbonne - paralleled the process in Spain, in an internal, natural and moderate fashion and, as far as we know (contrary to Barcelona, for example), without the intervention of the Christian authorities or the revocation of personal privileges, following a political struggle. ${ }^{31}$ Furthermore, unlike in Spain, the new leadership actually embraced the values of Andalusian adab brought by the Spanish immigrants, making these their founding ethos, while the old aristocracy had relied more on local tradition.

In his outline of the chain of tradition from Saadia Gaon to Maimonides, Jedaiah ha-Penini mentions a long line of Spanish scholars, most of whom are known to him exclusively through their work. With regard to one of them, however - Abraham Ibn Ezra - he cites an oral tradition describing the encounter between the Spanish scholar and the sages of Southern France, noting that he was the first to open their eyes to philosophy and science:

And after them, came the great sage Rabbi Abraham Ibn Ezra, famed in the gates. And he surpasses all of those mentioned, in understanding the truths, and waiting at the doors of wisdom, and dispelling erroneous beliefs concerning the verses of the Torah and the Prophets. And our fathers told us of the joy with which the great ones

30. Septimus, Hispano-Jewish Culture, esp. p. 70; Jonathan P. Decter, Iberian Jewish Literature: Between al-Andalus and Christian Europe, Bloomington IN, Indiana University Press, 2007, esp. pp. 1-18.

31. See Aryeh Grabois, "Neśi'ei Narbonah: li-Demutah u-le-mahutah šel hanhagah Yehudit bi-derom Șarfat bi-yemei ha-beinayim", Michael 12 (1991), pp. 9-41. 
of this land, its righteous men and its rabbis, greeted his arrival when he came to them. He began to open eyes in our provinces. ${ }^{32}$

As we know, Abraham bar Hiyya also visited Southern France and spread his teachings there. ${ }^{33}$ In Jedaiah's account, however, only his books are mentioned, and he does not feature in the collective memory as one who actually came to their land and left a lasting personal impression. Conversely, Abraham Ibn Ezra, is celebrated as a local "culture hero". Provençal historical consciousness preserved the memory of the encounter with Ibn Ezra as a founding event, and he was considered a founding hero who had brought about cultural change. After Ibn Ezra and even greater than him in the consciousness of the Jews of Southern France came Maimonides, whom they considered the greatest Jewish sage of all:

And all of his [Ibn Ezra's] books did not suffice, together with all of the books of the others, and the thirst of the learned was not fully quenched, so that God wished to purify Israel and brought forth the sun of the great rabbi, crown of the exalted, Rabbi Moses [Maimonides], peace upon him.... All told, he ascended the rungs of truth in peace and uprightness, more than any [of whom] we have heard, from the completion of the Talmud to this day. And so too in human philosophy, all that Aristotle had understood and all the commentaries on his books. And he restored in geometry, arithmetic and relations all that Euclid and his fellows had understood in them. And in astronomy, he knew all that was known of its mysteries to Ptolemy, called megistus, and his school. And he discovered in medicine all that Galen and Hippocrates and their schools had discovered. And in the realm of Torah, his mind encompassed all of the knowledge and interpretations known until

32. Jedaiah continues (Jedaiah ha-Penini, 'Iggeret ha-hitnașlut, in Forcano i Aparício, La Lletra Apologètica, pp. 397-398); "And he wrote for them commentaries on the Pentateuch and the Prophets, and wherever he feels there is something hidden, he draws attention to it, whether offering a full explanation or merely an intimation, as appropriate. He also wrote for them a small book called Yesod ha-mora' on the reasons behind the precepts, also briefly noting allusions (remazim). And [wrote] Sefer ha-šem, on the secret of the tetragrammaton, based on principles of arithmetic and geometry, with some philosophical observations as well. And he also wrote a commentary on Qohelet and Job, in which he follows the method of the rational scholars, and other books on grammar, in which he provides explanations derived from human wisdom for many of the principles of grammar and vocalisation and the forms of the letters. And other short books on astronomy and geometry and arithmetic and the secret of calendar calculation [ 'ibbur]"

33. See Yom Tov Assis, “'Galut Sefarad 'ašer be-Provans': 'Al mahapekhah tarbutit ve-datit be-Yahadut Provans ba-me'ot ha-12 ve-ha-13", Hispania Judaica 7 (2010), pp. 1-48. 
his time. And he engraved and combined [=writes, according to Sefer Yetzirah (e.g. 2,2)] within its secrets and mysteries, and grasped more of the truths of prophecy than any other author to whom such things had been revealed until the day of his passing. And the [doctrine of] corporeality had nearly spread to many distant places, when his holy books first appeared in the lands. And we see explicitly in many writings from the time of the first controversy, sent against him from the ends of the earth that they reproach him and denounce his books, for having said that the Creator of all things has neither measure nor image. We also see in the letter sent by the consummate sage Rabbi Moses ben Nahman [Nahmanides], of blessed memory, to the rabbis - the rabbis of France in those days, in which he argues before them, with many precious words that attest to his intelligence and wisdom, in defence of our great rabbi [Maimonides], of blessed memory, and especially in dispelling the [doctrine of] corporeality on account of which they had accused him. It would thus appear that corporeality was openly professed at that time. ${ }^{34}$

The cultural identity of the Jews of Southern France was also shaped by more recent events, in the generations immediately preceding the conflict with Ben Adret. Jedaiah ha-Penini mentions many letters from the previous controversy, surrounding the Guide of the Perplexed (which he calls "the first controversy"), present in the libraries of Provençal scholars. ${ }^{35}$ The previous controversy (1230-1233) was thus not merely a matter of literature or oral history, and its place in the collective memory was preserved, inter alia, by the inclusion of this correspondence in their libraries. Jedaiah gave particular prominence to two of these letters. The first is a letter from Nahmanides to the sages of France, in which Nahmanides stresses that Maimonides' books are a bulwark against the doctrine of divine corporeality. Nahmanides was also Solomon ben Adret's revered teacher. It is thus not surprising that Ha-Penini chooses to cite him to Ben Adret. At the same time, however, Ha-Penini ignores the far less pleasant - from his perspective continuation of Nahmanides' letter, in which he seeks to suppress the institutional, public study of philosophy in Southern France.

34. Jedaiah ha-Penini, 'Iggeret ha-hitnașlut, in Forcano i Aparício, La Lletra Apologètica, pp. 398-399; and with minor variations, in Še'elot u-tešuvot ha-Rašba', vol. 1, sec. 418, pp. 204-225.

35. On this controversy, see Azriel Shohat, "Beirurim be-farašat ha-pulmus ha-ri'šon 'al sifrei ha-Rambam", Zion 36 (1971), pp. 27-60; Joseph Shatzmiller, "Li-temunat ha-mahloqet ha-ri'šonah 'al kitvei ha-Rambam", Zion 34 (1969), pp. 126-144; Daniel Jeremy Silver, Maimonidean Criticism and the Maimonidean Controversy 1180-1240, Leiden, Brill, 1965. 
Alongside Nahmanides, Jedaiah cites another member of the Kabbalistic circle of Girona, Meshullam de Piera:

So too the sage and poet En Vidas [Meshullam de Piera] attested regarding the great men of his land [the Kabbalistic circle of Girona], perhaps in jest or unjustly casting aspersions, that they ascribe measure to their Creator, but their words, for fear of the heretics [the philosophers of Southern France], they have ceased. Note the great ill, that those who dispelled measure [the philosophers] were heretics in his eyes. Yet today, praise to God, that wholly evil belief has been completely eradicated from all our factions, and we know of no one who entertains it in the slightest or is confused and uncertain about it, whether by absolute logical demonstration or by tradition. And indeed if no other benefit to our people were to have emerged and been attained from the philosophical discourse of our great rabbi [Maimonides], it would truly have sufficed, and we would have been duty-bound to praise and glorify his broad wisdom that brought him to the truth. ${ }^{36}$

The poet Meshullam de Piera was one of the most prominent opponents of Maimonides during the first controversy. He devoted seven scathing poems to the debate with Maimonides, followed by an eighth, "Yehegu mezimotai" [They speak of my machinations] - probably written following instructions from Nahmanides in which he expressed qualified remorse. The lines quoted by Jedaiah ha-Penini are from the poem "Yirbu mezimmotai" [My machinations increase]. In this poem, Meshullam names his allies in the debate with Maimonides, including: in Languedoc, Solomon ben Abraham of Montpellier (Min hahar); and in Girona, Nahmanides and his two teachers of Kabbalah, Ezra and Azriel. Of the circle of Kabbalists he writes:

They are my priests.... They know sefer, sefar and sippur [writing, number and speech; a reference to Sefer yeșirah] / indeed to recount the glory [the Shekhinah or the secrets of the Kabbalah] they are cautious // They ascribe measure to their Creator, but their words, for fear of the heretics, they have ceased. ${ }^{37}$

In this polemical poem, De Piera admits that the Kabbalists of Girona ascribe corporeality and measure to God, but do not do so

36. Jedaiah ha-Penini, 'Iggeret ha-hitnașlut, in Forcano i Aparício, La Lletra Apologètica, p. 399.

37. Meshullam de Piera, Yirbu mezimmotai, in Heinrich Brody, "Širei Mešullam bar Šelomoh Da'pie'ira", Studies of the Research Institute for Hebrew Poetry in Jerusalem 4 (1938), p. 104; Haim Schirmann, Toledot ha-širah ha- 'Ivrit bi-Sefarad ha-Noșrit u-vi-derom Sarfat, edited, completed and annotated by Ezra Fleischer, Jerusalem, Magnes Press, 1997, pp. 315-316, n. 136. 
openly, for fear of the philosophers. A number of scholars have explained De Piera's phrase "for fear of the heretics" as referring to the fear of revealing the secrets of the Kabbalah, which might lead to misunderstanding and heresy. ${ }^{38}$ That is not how Jedaiah understood the phrase, however, and I believe he was right. The heretics in De Piera's poem are the same Provençal philosophers who supported Maimonides. In his poems De Piera presents Southern France as the land of heretics and deniers, and condemns its Andalusian ethos, which he sought to replace with the study of the Talmud and Kabbalah.

De Piera laments the decline of this territory: "The land of Provinșah was full of delight / but the transformations transformed your land." 39 The "transformations" are the gradual historicocultural process during the course of which the diffusion of the Guide of the Perplexed was completed, and Southern France became the land of the philosophers - whom De Piera calls heretics and deniers: "A land prone, there it already nested / [there] deniers brooded heresy and destruction." ${ }^{40}$ This cultural process began and developed in the mid-twelfth century, through the endeavours of Andalusian immigrants Joseph Kimhi and Judah Ibn Tibbon. In order to further scientific study at the expense of the centrality of the Talmud, Joseph Kimhi established the science of Hebrew grammar as a key subject and, in so doing, even sought to undermine the authority of the prominent leader of the Jews of northen France, the tosafist Jacob Tam, whose influence among the Jews of Southern France was growing at that very time. ${ }^{41}$ Meshullam de Piera criticises this phenomenon in another poem, in which he mocks the traditional Spanish-Andalusian ethos, which he now wishes to replace with the study of Talmud and Kabbalah:

The [talmudic] study halls are my habitual places of study / tents for [studying] the tractate of Tents.

38. See Brody, "Širei Mešullam", p. 104; Schirmann and Fleischer, Toledot ha-širah ha-'Ivrit, pp. 315-316.

39. From De Piera's poem Hai ha-berit, in Brody, "Širei Mešullam”, p. 97. The poem may have been sent to the Provençal poet Isaac ha-Sniri, See Schirmann and Fleischer, Toledot ha-širah ha- 'Ivrit, p. 287, n. 77, 453, n.105.

40. From De Piera's poem Yirbu mezimmotai, in Brody, "Širei Mešullam", p. 104. In my opinion, this image of Jewish Provence as a land of heresy and denial draws upon the Church image of Provence as a land of Cathar heresy.

41. See Ben-Shalom, The Jews of Provence, pp. 420-426. 
The laws of prayer I have learned from [the chapter] "One should not stand up" [Berakhot 5] / and the order of inheritance from [the chapter] "Some inherit" [Bava' batra' 8].

I have also understood the mysteries of Sefer yeșirah / and the foundation of the seven double letters.

But what purpose do po'el, kal and pa'al serve? / Will actions (pe 'ulot) proceed from their activity (pe 'ulatam)?

Will the language of a square [four-radical] verb teach us / diagonals and the squares of circles?

Have you ever seen a grammarian rabbi and judge / or one of the vocalisers lead a community?

In a tarha' [accentuation mark] you will see travail (torah) and toil / and you will find no benefit (segullah) in [letters vocalised with a] segol.

And the scripturists find great mystery in the labial consonants / and the spirantised letters.

They study Jeremiah, Micah and Amos / but see before them the foundations of grammar and vocabulary.

And they hold Kimhi's remembrance dear / and in their mouths are songs of praise for ha- Dar 'i [probably Judah Hayyuj].

But [there is] disagreement in Šorašim and Riqmah / and I found questions in Haśśagah!

They may, in the matter of the vocalisation of [the word] yemeihem, / toil in vain and their hearts grow weak.

It is enough for me to examine the action / to distinguish between masculine and feminine participles.

And what do I care for strong verbs / and for those that have weak letters? ${ }^{42}$

De Piera criticises the Andalusian school of grammarians, citing three of the works associated with it, by the grammarian Jonah Ibn Janah: Sefer ha-šorašim, Sefer ha-riqmah and Sefer ha-haśśagah. The first two were translated by Judah Ibn Tibbon, and the third by Obadiah ha-Sefaradi (in the late twelfth century). Of the leading grammarians, Joseph Kimhi is mentioned by name, and the phrase "they hold Kimhi's remembrance dear" alludes to Kimhi's work on Hebrew grammar: Sefer ha-zikaron [Book of Remembrance]. Haim Schirmann and Ezra Fleischer note that no Spanish scholar would have dared to make light of or mock the study of the Hebrew

42. From De Piera's poem Be-'oznai yittenu qol, in Brody, "Širei Mešullam", pp. 41-42. See Schirmann and Fleischer, Toledot ha-širah ha- 'Ivrit, p. 296, n. 73. The negative characterisation of the grammarians as "toilers in vain" (yegi 'ei riq) was known already in Muslim Spain, and is reflected in Jonah Ibn Janah, Sefer ha-riqmah (Kitäb al-luma'), translated by Judah Ibn Tibbon, ed. M. Wilensky, Jerusaelm, Academy of the Hebrew Language, 1964, introduction, pp.11-12: "he who engages in it toils in vain" ( $u$-ve 'aleha yage 'a la-riq). De Piera appears to have been quite familiar with Ibn Janah's Sefer ha-riqmah, mentioned in this poem. 
language, which had been a pillar of the Sefardic ethos since the time of Menahem ben Saruq and Dunash ben Labrat:;3 De Piera's attack is clearly not limited to matters of culture, seemingly detached from the burning issues within Jewish society of the day. The connection between societal institutions and cultural values is reflected in the line: "Have you ever seen a grammarian rabbi and judge / or one of the vocalisers lead a community?" In other words, De Piera was not merely referring to a cultural struggle, but rather to a political dispute concerning positions of power within the community and the important institutional roles of rabbi and rabbinical court judge.

Jedaiah cites De Piera's words in order to show how much the Provençal historical-cultural movement - heir to the Andalusian tradition - was really needed, in order to dispel the doctrine of corporeality. He uses the poet's words in order to prove to Solomon ben Adret that those who believed in the corporeality of God in previous generations were, in fact, a formidable and active social force, which is why the spiritual movement of philosophy was and remains essential. In so doing, he would also appear to be implying that Ben Adret, a Kabbalist (and leader of the Kabbalistic circle in Barcelona), might be perceived - both in his opposition to philosophy and as heir to one of the Kabbalistic circles of Girona as subscribing to corporeality himself.

We must not conclude from Jedaiah ha-Penini's words, however, that the unique character of Provençal Jewry lay exclusively in its Maimonidean philosophical approach. 'Iggeret ha-hitnașlut - Epistle of Apology - is, as its name indicates, an apologia, in which the author sought to present a particular aspect of Provençal Jewish culture, in order to frustrate Ben Adret's designs. Similarly, during the controversy, both sides tended to give greater prominence to the Maimonidean, Andalusian image of the Jews of Southern France. Nevertheless, I believe there can be no doubt that the cultural agenda of the Andalusian refugees Judah Ibn Tibbon and Joseph Kimhi became, over time, the primary marker of identity among a central component of Provençal Jewry. In its own eyes, this group considered itself and all of the Jews of Provence, Languedoc and Roussillon the "true" heirs of Spanish Jewry.

Ram.Ben-Shalom@mail.huji.ac.il

43. See Schirmann and Fleischer, Toledot ha-širah ha- 'Ivrit, p. 296, n. 72. 